\title{
Correlation between Red Cell Distribution Width (RDW) with Kidney Function and Hematologic Parameters in Patients undergo Regular Hemodialysis
}

\author{
Soraya Mourina Hutasuhut*, Alwi Thamrin Nasution, M. Feldy Gazaly \\ Nasution
}

Division of Renal and Hypertension, Department of Internal Medicine Faculty of Medicine, Universitas Sumatra Utara, Medan Indonesia.

\begin{abstract}
Background: Red cell distribution width (RDW) is the coefficient of variation in red blood cells. RDW may increase due to a deficit from erythropoiesis or an increase in red blood cell destruction. The aim of this study was to determine the correlation of RDW as a marker of inflammation with renal function and hematological parameters in patients undergoing regular hemodialysis. Method: A cross-sectional study using data from 20 patients undergoing routine hemodialysis > 3 months at RSUP H Adam Malik Medan. Vital sign, antropometry and venous blood retrieval are performed shortly before hemodialysis. RDW measurement comes from the red blood cell distribution curve in hematological analysis and is an indicator of variation in red blood cell size. Result: From 20 samples, 14 (70.0\%) had comorbid Diabetes mellitus (DM), followed by hypertension by 4 (20.0\%). The mean length of time for patients to undergo HD was $24.45 \pm 20.98$ months. There is a significant correlation between RDW with creatinine, Hb, and neutropyl (r: 0.519, p: 0.019 *; r: 0.497, p: $0.026 *$; r: 0.464, p: $0.039 *$, respectively). Conclusion: There is a significant relationship between RDW and creatinine, $\mathrm{Hb}$ and neutropphils in patients undergoing regular hemodialysis $>3$ months.
\end{abstract}

Keyword: RDW, Kidney Function, Hematology Parameters

\begin{abstract}
Abstrak. Latar belakang: Red cell distribution width (RDW) merupakan koefisien variasi pada sel darah merah yang bisa meningkat karena defisit eritropoesis atau peningkatan destruksi sel darah merah. Tujuan Penelitian: Untuk mengetahui hubungan RDW sebagai marker inflamasi dengan fungsi ginjal dan parameter hematologi pada pasien yang menjalani hemodialisis regular. Metode: Penelitian bersifat potong lintang terhadap 20 pasien yang menjalani hemodialisis reguler > 3 bulan di RSUP H Adam Malik. Dilakukan pemeriksaan vital sign, antopometri dan pengambilan darah vena untuk pemeriksaan darah rutin yang dilakukan sesaat sebelum hemodialysis. Pengukuran RDW berasal dari kurva distribusi sel darah merah pada analisis hematologi dan merupakan indikator variasi ukuran sel darah merah.. Hasil: Dari 20 subjek penelitian, mayoritas subjek memiliki penyakit komorbid diabetes mellitus 14 orang (70.0\%), hipertensi 4 orang (20.0\%). Rata-rata lama pasien menjalani hemodialisis $24.45 \pm 20.98$ bulan. Terdapat korelasi yang signifikan antara RDW dengan kreatinin, Hb, dan neutropil ( $r: 0,519, p: 0,019 * ; r: 0,497, p: 0,026^{*} ; r: 0,464$, p: 0.039*, secara beurutan). Kesimpulan: Terdapat hubungan yang signifikan antara RDW
\end{abstract}

*Corresponding author at: Division of Renal and Hypertension, Department of Internal Medicine Faculty of Medicine, Universitas Sumatra Utara, Medan Indonesia.

E-mail address: sorayamourina@yahoo.co.id 
dengan kreatinin, $\mathrm{Hb}$ dan neutropfil pada pasien yang menjalani hemodialisis regular > 3 bulan.

Kata Kunci: RDW, Fungsi Ginjal, hematologi parameter

Received 14 October 2020 | Revised 23 November 2020 | Accepted 30 November 2020

\section{Introduction}

Red cell distribution width (RDW) is the coefficient of variation in red blood cells (RBC) could increase due to the deficit of erythropoiesis or the enhancement of the destruction of blood red cells. Patients with chronic kidney disease (CKD) and anemia are known as a risk factor of cardiovascular disease. RDW increased significantly in patients with CKD stage 1 up to 5, where increasingly high RDW correlated with higher staging [1]. The value of RDW increased in CKD that degree one up to level five with values > 13.5 [2]. RDW is closely associated with kidney function measured by assessing albumin-creatinine ratio in hypertensive patients. In that study, it was stated that RDW was greater than 12.8 measured in early hypertensive patients having $76 \%$ sensitivity and $70 \%$ specificity in predicting early-stage damage to renal function [3].

In the study, the first of the 1293 incident peritoneal dialysis are RDW $\geq 15.5 \%$ as much as $60 \%$, and $27 \%$ of them had a risk of cardiovascular compared with RDW $\leq 15.5 \%$. In a prospective study, both of the 100 patients on hemodialysis showed every increase of $1 \%$ RDW associated with a 54\% risk of causing mortality when they followed up one year [4].

The purpose of the research is to analyze the relationship between RDW with kidney function, and hematologic parameters in patients undergo regular hemodialysis for $>3$ months.

\section{Method}

In this research, the target population are patients who undergo hemodialysis regularly in the $\mathrm{H}$. Adam Malik General Hospital Medan in 2020 with cross-sectional studies. Inclusion criteria: patients were men and women were aged $\geq 18$ years, undergoing regular hemodialysis $>3$ months. Exclusion criteria: patients with a history of liver disease, patients with infection, and patients with malignancy. Sample studies were selected consecutively. The patient examination includes vital signs, anthropometric, and taking veins blood to analyze routine blood. Taking a sample of blood is done shortly before the hemodialysis session. RDW measurement comes from the red blood cell distribution curve in hematology analysis and is an indicator of variation in red blood cell size in blood samples (Cao, 2019). 


\subsection{Data Analysis}

The analysis of univariate and bivariate against the data was done in the study. Univariate analysis was performed to obtain the distribution of sample characteristics. Bivariate analysis was performed to determine the relationship between the independent and dependent variables. Normalities test were done with test Shapiro-Wilk test. The statistic test used was a correlative Pearson test with an alternative Spearman test for not normal distribution. Analysis using a computerized program SPSS 23 ( Statistical Product and Service Solution ) and 95\% confidence interval, the value is significant if $\mathrm{p}<0.05$.

\section{Result}

Research Sample Characteristics. The study was conducted on 20 subjects who had met the inclusion criteria. A total of 13 people were men (65.0\%) and seven women (35.0\%). The majority of subjects had diabetes mellitus comorbid 14 (70.0\%), followed by hypertension 4 (20.0\%). The mean length of time for patients to undergo hemodialysis was $24.45 \pm 20.98$ months (table 1).

Table 1 Research Sample Characteristic

\begin{tabular}{lc}
\hline Characteristic & $\mathbf{n = 2 0}$ \\
\hline Sex, F/M & $7 / 13$ \\
Age (years), Mean $\pm \mathrm{SD}$ & $50.30 \pm 12.57$ \\
Length of hemodialysis (Months) & $24.45 \pm 20.98$ \\
Hypertension, n(\%) & $4(20.0 \%)$ \\
Diabetes Mellitus, n (\%) & $14(70.0 \%)$ \\
Glumerulonephritis, n (\%) & $2(10.0 \%)$ \\
Hb (g/dL) & $9.12 \pm 0.57$ \\
Ureum (mg/dL) & $147.1 \pm 33.62$ \\
Creatinine (mg/dL) & $10.1 \pm 4.02$ \\
eGFR (ml/min) & $5.95 \pm 3.11$ \\
albumin (mg/L) & $3.2 \pm 0.65$ \\
RDW & $15.93 \pm 1.87$ \\
\hline
\end{tabular}

In Table 2, There is significant correlation between RDW and $\mathrm{Hb}$, neutrophil, and creatinine. 
Table 2 Correlation Between RDW with Kidney Function and Hematologic Parameter

\begin{tabular}{lcc}
\hline \multicolumn{1}{c}{ Parameters } & $\mathbf{r}$ & $\mathbf{p}$ \\
\hline $\begin{array}{l}\text { Hematology } \\
\text { Hb }\end{array}$ & 0.497 & $0.026^{*}$ \\
Eosinophil & 0.317 & 0.174 \\
Basophil & 0.345 & 0.137 \\
Neutrophil & 0.464 & $0.039 *$ \\
Lymphocyte & 0.379 & 0.099 \\
Kidney Function & & \\
Ureum & 0.124 & 0.603 \\
Creatinine & 0.519 & $0.019^{*}$ \\
eGFR & 0.379 & 0.100 \\
\hline *p $<0.05$ & &
\end{tabular}

\section{Discussion}

RDW is a parameter related to the heterogenicity of red blood cell volume and is used as a differential diagnosis of anemia. The RDW measurement comes from the red blood cell distribution curve in hematological analysis and indicates the variation in the size of red blood cells in blood samples [5].

The value of normal RBC varies from 80 to $100 \mathrm{fL}$ in the blood. The clinical condition of red blood cells can be increased or decreased. The production of red blood cells is not effective, including deficiency of iron, vitamin B12 and folate, destruction of red blood cells, and blood transfusion [6]. RDW value that increase reflects the variability that is large in size red blood cells show dysfunction of erythropoiesis, a period of living cells of blood red that is short, or the release of reticulocytes prematurely [7].

In the circumstances specific, red blood cells may experience an increase or decrease in volume is typical. The plasma membrane's intrinsic plasticity and the relatively modest content of intracellular molecules (especially hemoglobin) allow contraction and changes in erythrocytes' size and volume. Erythrocyte can swell up to form round $150 \mathrm{fL}$ (macrocytosis), or shrink up to $60 \mathrm{fL}$ or even lower (microcytosis) [8].

The hormone erythropoietin which regulates the production, maturation, and survival of bone marrow erythrocytes is one of the main determinants of RDW [9]. It has been shown that abnormal erythropoietin production and erythropoietin hyporesponsiveness can induce a gradual increase in RDW values [10]

According to Cao et al 2019, patients with RDW> $15 \%$ will experience an incident occurrence of cardiovascular $16.7 \%$, and in patients with hemodialysis, the occurrence of cardiovascular disease 
as much as $48 \%$. The incidence of cardiovascular disease increased at RDW $\geq 15 \%$ compared to $\mathrm{RDW} \leq 15 \%$ [5]. Decreased eGFR of $10 \mathrm{ml} / \mathrm{min}$ is associated with an increase in RDW [11]. In research by Solak et al, measuring the RDW in 367 patients with CKD stage 1 to 5 , the values of RDW increased significantly from stage 1 to 5 , and shows the correlation were significantly and inversely with the value of eGFR $(r=-0.58 ; p<0.001)[12]$.

In this study, there was a significant relationship with creatine in (r: 0.519; p: 0.019*) only, while the other hematology parameters were $\mathrm{Hb}$ and neutrophils (r: 0.497, p: 0.026*; r: 0.464: p:0.039*, respectively). The study's difference was due to the patient having undergone hematological improvement by interventions such as iron, transfusion and erythropoietin administration.

\section{Conclusion}

There is a significant relationship between RDW with creatinine in the patients who undergo regular hemodialysis $>3$ months.

\section{References}

[1] Lu, Y., Fan, P., Lee, C., Wu., V. C., Tian, Y., Yang, C., et al.. Red cell distribution width associated with adverse cardiovascular outcomes in patients with chronic kidney disease. BMC Nephrol. Vol. 18, No. 1, p:361. 2017.

[2] Yonemoto S, Hamano T, Fujii N, Shimada K, Yamaguchi S, Matsumoto A,et al. Red cell distribution width and renal outcome in patients with non-dialysis-dependent chronic kidney disease. PLoS ONE; vol. 13, p: e0198825. 2018.

[3] Li, Z., Chen, L., Yuan, H., Zhao, T. and Kuang, Z. Relationship Between Red Cell Distribution Width and Early-stage Renal Function Damage in Patients with Essential Hypertension. J Hypertens. vol. 32, no. 12, p:2450-5. 2014.

[4] Vashistha, T., Streja, E., Molnar, M. Z., Rhee, C. M., Moradi, H., Sooho, M., et al. Red Cell Distribution Width and Mortality in Hemodialisis Patients. Am J Kidney Dis. Vol.68, p:110. 2016.

[5] Cao HX, Zhao X, Yan L, Fan X, Shao F. Correlation between red blood cell distribution width and cardiovascular events in the patients receiving peritoneal dialysis: A Strobecompliant article. Observational Study. Medicine (Baltimore). Vol. 98, no. 6, p:e14376. 2019.

[6] Li N, Zhou H, Tang Q. Red Blood Cell Distribution Width: A Novel Predictive Indicator for Cardiovascular and Cerebrovascular Diseases. Dis Markers. p:7089493. 2017.

[7] Said, A. S., Spinella, P. C., Hartman, M. E., Katherine, M., Steffen.. RBC Distribution Width: Biomarker for Red Cell Dysfunction and Critical Illness Outcome?. Critical care Med. Vol.18, no. 2, p:134-42. 2016.

[8] Franco RS. The measurement and importance of red cell survival. American Journal of Hematology vol. 84, p:109-14. 2009.

[9] Lippi G, Plebani M. Red blood cell distribution width (RDW) and human pathology. One size fits all. Clin Chem Lab Med vol. 52, no. 9, p:1247-9. 2014 doi: 10.1515/cclm-20140585 .

[10] Afsar, B., Saglam, M., Yuceturk, C., Agca, E.. The relationship between red cell distribution width with erythropoietin resistance in iron replete hemodialysis patients. Eur J Intern Med vol. 24, p: e25-9. 2013.

[11] Ujszaszi, A., Molnar, M. Z., Czira, M.E., Norvak, M., and Mucsi, I. Renal function is 2019 independently associated with red cell distribution width in kidney transplant recipients: a potential new auxiliary parameter for the clinical evaluation of patients with chronic kidney disease. Br J Haematol vol,161, p:715-25. 2013. 
[12] Solak Y, Yilmaz MI, Saglam M, Saglam M, Caglar K, Verim M, et al., "Red cell distribution width is independently related to endothelial dysfunction in patients with chronic kidney disease," The American Journal of the Medical Sciences, vol. 347, no. 2, p:118-24, 2014. 